\title{
INTEGRATING CHARACTER BUILDING INTO TEACHING TO ENHANCE THE STUDENTS ENVIRONMENTAL AWARENESS
}

\author{
Lestari Setyowati \\ STKIP PGRI Pasuruan. \\ lestari.setyowati@yahoo.co.id
}

\begin{abstract}
Due to the growing environmental destruction, it is becoming necessary for people to start to care about the place they live. One way of doing this is through education by making the students aware of their environmental problems. However, the character education in Indonesia focuses more on improving the quality within and between individuals, and seems to neglect the characters, which shows relationship with environment. Creating students who are environmentally aware and able to take participation to protect their environment basically helps them to posses good moral values. In short, possessing characters which signifies awareness to environmental problems and ability to protect the environment is as important as possessing desirable characters that can help students to succeed in live. This paper discusses about the characters building within Indonesian context, environmental education, language learning and environmental education, and some proposed models to integrate environmental education into teaching
\end{abstract}

Keywords: Character building, environmental education, models.

As teachers in the 21st century, we are faced with serious global problems, such as wars, terrorism, gender inequality, social inequality, racism, and environmental destruction. One of the global issues which is considered the most urgent and need immediate solution is the environmental problems. Global warming, draught, flood, landslides are some examples of the environmental issues which are posed almost every day in news, bulletin, TV, and other kinds of media. So, it is not exaggerating to say that environmental problems are near and urgent to be solved because they affect people globally and directly (Cates, 1990). These environmental problems happen because of human unfriendly behavior toward nature, such as illegal logging, pollution on water, land, soil, air, waste disposal and many other. The most unfriendly behavior toward the environment which are observable daily and very near happened in the surrounding environment are the habits of throwing rubbish, and the irresponsible use of plastics. Since they become habit, it is not strange and very common to see someone throwing a bag full of garbage into the river, kids throwing their plastic snacks everywhere, and people's use of plastic bags for almost everything. Because of these, it is becoming urgent to broaden people's environmental awareness so that they can appreciate nature better.

At this point, schools take an important role in educating the younger generations to be better citizens in relation to the environmental awareness and their willingness to take participation in protecting the earth. Schools are not only places to learn cognitive skills. As argued by Raddy (2007), schools 
also serve as an instrument in developing desirable non-cognitive outcomes. They are places for students to reveal their self-identity, to learn to work together, to appreciate differences, to learn about responsibility and consequences, to practice discipline and honesty, to learn protecting their environment, to grow the feeling of compassion not only to other individual but also to non-human living things, such as animals, plants, and nature, and many other expected traits. These affective skills are called 'characters building'. Unfortunately, within Indonesia context, the expected characters that students should have do not touch the traits that can trigger students inner consciousness to be able to feel compassionate to nature and protect the environment. The inclusion of these characters within Indonesian education system would be very beneficial in creating sustainable development so that in the future these young generations can take active participation in decreasing and preventing the environmental destruction as well as protecting the environment. This paper, thus, will discuss about characters building in Indonesian education system, its relation to the environmental education, language learning and environmental education, and the proposed models on the implementation of character building in teaching that can enhance the students environmental awareness.

\section{Characters Building}

Characters education has found its place in Indonesian education system, basically, since character building becomes one of the aims of national education as stated in Law Number 1 Year 2003 on the National Education System (Suyanto, 2009; Kemdiknas, 2010). It is then elaborated in the Indonesian Law no 17 Year 2007 about Long Term Plan of National Education (RPJPN) 2005 - 2025. The characters required for the students are strong, competitive, good moral, tolerable, patriotic, dynamic, culture-minded, IT-oriented based on Pancasila and faith to God. The Curriculum Center of Indonesia then developed the four minimal characters into seventeen characters expected to be acquired by the students during their formal learning in schools. The characters required are religious, honest, intelligent, strong, caring, responsible, learning initiative, discipline, perseverant, appreciative to diversity, contributive, optimistic, open, risk taking, committed, and sharing (Malino, 2012).

These seventeen characters above basically are in line with the six universal characters or six ethical values proposed by Michael Josephson, the president of Josephson Institute (Education World, 2011). The universal values under six broad categories are trustworthiness, respect, responsibility, fairness, caring, and citizenship. Other resources sometimes also include three additional topics namely courage, diligence, and integrity. One big difference between Indonesian character building and the universal values is that our values of characters building are religiously and culturally biased. However, despite of the difference, both set of values (Indonesian characters and universal characters) shared commonalities, first, they are directed toward the creation of 'ethical' individual, and second, they are directed toward the creation of good citizenship that can live in harmony with other people. Thus, the focus of character building is basically to improve the quality of individuals, within individuals and between individuals.

Having students who are morally good, caring, responsible, open to any diversity are likely to achieve better success in life than those who are only good academically. Character building is not just 'moral education'. It does have something to do with students academic performance. Daniel Goleman (in Suyanto, 2009), the writer of Emotional Intelligence, writes that someone's success in society is very much influenced by his/her emotional intelligence, not solely on the intel- 
ligence. The characters of this emotional intelligence that can help individual to succeed are confident, cooperative, emphatic, and communicative. Education goal, thus, should be directed toward both creating intelligent individuals and strong character individuals. As stated by Dr. Martin Luther King (in Suyanto, 2009), "intelligence plus character... that is the goal of true education".

Indonesian education system, basically have combined these 'intelligence plus character' goal. This has been stated clearly in Law Number 1 Year 2003 on the National Education System. As what has been discussed above, in Indonesian context, there are seventeen characters expected to be acquired by the students. As cited from Malino (2012), those characters are 1) honest (religiously, fair, ikhlas, positive thinking), intelligent (creative, self-control, humble, economical), 3) strong (independent, confident, responsible, discipline, hard working, perseverant), 4) caring (compassionate, tolerant, polite, peaceful lover, cooperative, nation loving), 5) honest, 6) responsibility, 7) learning initiative, 8) self- discipline, 9) perseverant, 10) appreciative to diversity, 11) contributive, 12) optimistic, 13) honest, 14) open, 15) risk taking, 16) committed, and 17) sharing. Since Pancasila is the ideology of Indonesia, and hundreds of culture are living in the country, it becomes understandable why those characters building in Indonesian Education system are religiously and culturally biased.

Based on the manual of character education released by Kemdiknas (2010), the cultivation of character building can be done in two ways, namely intervention and habituation. Intervention means that the character education should be done integrately during the teaching and learning process by employing Contextual Teaching and Learning approach (CTL). CTL principals are considered appropriate to facilitate the internalization of those moral values. In the habituation strategy, the students characters are shaped by repeated ac- tivities and routines school schedules. Purnomo (2012) believes that high discipline school atmosphere will influence the students' lives at school and outside school. The habituation strategy covers the implementation of nation characters values to school culture, school/ class rules and regulations, models that students can imitate, and creating conducive school atmosphere. One example of habituation is through routines classroom activities, such as checking attendance (discipline), praying before starting the lesson (religious), doing assignments individually (honesty), etc. Thus, through the process of habituation and intervention, the expected characters will be internalized and personalized.

If we take a look at the seventeen characters within Indonesian education system, all of them show the expected quality that individuals should acquire, that is to improve the self-quality and to have better relationship with other individuals and society. However, living in the 21st century when the world faces problems of environmental destruction, the characters required which show awareness and protection to the environment, explicitly or implicitly, should be added. Teachers need to grow a deep concern of loving and respecting the ecosystem. Before 'acting green' becomes an action, students need to 'think green' first. And this ecological awareness can be started at school, triggered by teachers that can show the students the importance to live side by side and in harmony with nature. Thus, we need to start to think that helping students to acquire the good characters that enable students to love and protect the environment is just as important as helping them to acquire the 'good' self characters that enable them to function well in society and to succeed in live.

\section{Environmental Education}

The whole world nowadays has been so concerned with global issues in general and environmental education and protection in 
particular. As a result, today in many fields of studies there is an increasing awareness to protect the ecosystem by 'thinking green' and 'acting green'. This concept of the environmental education, actually, has a long history. The question of environmental education emerged in 1972 when the United Nations Conference of that year encouraged member states to start thinking about global environmental problems ( Nkwetisama, 2011). The conference laid lots of emphases on environmental education. Then, the key movement to the development of global issues education was provided by the United Nations in 1975 when it organized an International Environmental Education Workshop in Belgrade. This resulted in the Belgrade Charter (UNESCO-UNEP, 1976) which set out six objectives for environmental education:

\section{Awareness, acquiring an awareness of envi- ronmental problems.}

As defined by Nkwetisama (2011) environmental education is conscientiously organized efforts to teach or draw human attention about how natural environments function and how these human beings are able to manage and protect their environment. Environmental education covers a wide range issues in which its endangerment is caused by human activities. As cited from Nkwetisama(2011), the environmental issues include global warming, greenhouse gas, ozone depletion, species extinction, poaching, endangered species, inefficient energy use, habitat destruction, air quality, light, noise and visual pollution, pollution of water like ocean dumping, oil spills and urban runoffs; electromagnetic radiation and health, nuclear proliferation and fallout, genetically modified foods, overgrazing, excessive use of pesticides and herbicides, intensive farming, land pollution and desertification, soil erosion and contamination, water crises, overfishing, illegal logging and deforestation.

Looking at the objectives of environmental education above, awareness to environmental problem basically is superficial. Jacobs and Goatly (2000) confirmed this by stating that being aware of the problems, understanding why they occur, caring and having the skills to overcome the problems, and having the ability to evaluate different solutions means nothing if there is no action taken. From this, it can be summed up that the most important objective to environmental education actually is participation.

\section{Language Learning And Environmental Ed- ucation}

Cates (1990) states that there are several good reasons why we should care about world problems. One is ethical and second is personal. It is ethical because he believes that it is morally wrong to "just stick the heads" into the textbooks and pretend that these problems do not exist. Another reason concerns with the "profession" of being a language teacher. The professions have a moral responsibility to do good things to society through the practice of their particular skills. Thus, within the scope of Socially Responsible Teaching (SRT), teachers have a moral responsibility to society in the practice of their specialized skills to solve world problems (Gürsoy and Sağlam, 2011). Furthermore, environmental issues fit well with Content Based Instruction (CBI) or Content and Language Integrated Learning (CLIL) and Theme-based teaching in which its aim is to teach language through content (Cates, 1990; Gürsoy, 2010; Gürsoy and Sağlam, 2011). CBI and CLIL then enable the learners to encounter the target language meaningfully and to gain knowledge about a subject that is not language related. The approaches also provide great opportunity for learners to make language learning and environmental education possible.

With the number of challenges that our planet faces today, raising students' environmental awareness and teaching them about the environmental values seemed to be very 
necessary to do. There are some advantages of integrating environmental education into the language classroom. As stated by Hauschild, et al (2012), the benefits of doing that are, first, environmental issues heighten students' interest in contemporary issues that might directly influence their futures; second, the issues teach students how to contribute to a healthier, more sustainable world; and third, it promotes language learning and meaningful communication.

As recently, the concerns for the environment have increased worldwide, it has become easier to find instructional materials for the language classroom. Many language textbooks now include chapters on environmental topics Hauschild, et al (2012). Furthermore, teachers can use the Internet, where available, to find environment-related resources that can be adapted to meet their students' content- and language-learning needs. It is also becoming more and more common for language teachers and instructors around the world to integrate environmental issues through their materials, techniques, media, classroom activities, syllabus design(Cates, 1990). Teachers nowadays can easily find abundant lists of "green" resources - including environmental curricula, lesson plans, pictures, flashcards, poems, songs, videos, graded readers, and art projects - in websites provided by environmentalists, teaching experts, teachers association, government institution, etc.

\section{The Models}

There are many ways that teachers can do to make the students, not only aware of the environmental problems, but also active in taking steps to participate in the protection of the environment. Those ways can be integrated into classroom activities when the teaching and learning process are conducted. The suitable classroom activities dealing with environment issues, by and by, can grow the students moral values to nature. The cultiva- tion of the expected characters within each individual are derived from the six objectives of environmental education proposed by UNESCO in 1976, namely 1) awareness of environmental problems, 2) basic understanding of the environment and its problems, and human, beings' role in relation to the environment, 3) attitude of concern for environmental problems, 4) skills in overcoming environmental problems, 5) ability to evaluate proposed solutions to environmental problems, and 6) participation in solving environmental problems.

Though according to Jacobs and Goatley (2000) participation becomes "the special importance". Students, however, may not be able to participate if they are not aware of the problems and have inadequate knowledge about the issue. Therefore, in this section, I propose two kinds of model; model 1 focuses more on the growing awareness and knowledge about environmental issue, and model 2 give more emphasizes on participation in solving environmental problems. Some activities in the former model (Model 1) are adopted from Hauschild et al (2012). The latter model (Model 2) is taken from Jacobs and Goatley (2000) in which some examples of the activities are also adjusted to Indonesian context. Jacobs and Goatley models were originally the coding system categories of their research on environmental issues in ELT course books. According to these researchers, the categories have been consulted to two professors who teach environmental education. In this paper the examples of each categories are given based on Indonesian context.

\section{Model 1}

\section{a. Discrete-skills instruction}

Despite of the facts that Content-Based Instruction fits so well with integrated-skills instruction, environmental topics can still be used to teach discrete skills. For example, to practice grammar, teachers can integrate simple facts about the environment 
into exercises that focus on imperatives (e.g., Turn off the light when you don't use it), verb tenses (e.g., Because of the global warming, the ice in the north pole is melting), and Wh- questions (e.g., What happens to our forest in Kalimantan?). Environmental texts can be downloaded from websites to be used for skimming, scanning, and note-taking practice in reading classrooms. The texts can also be used to promote critical thinking skills, as intermediate and advanced learners learn to distinguish fact from opinion, recognize bias, and provide oral responses to potentially controversial information. Statistics and numerical data about "green" topics can be used in dictations to help students practice numbers (Hauschild et al, 2012).

\section{b. Integrated-skills instruction through project work}

This activities can be done in several ways: 1) students do a research on topics of interest to be written for academic papers , (2) writing and illustrating children's books or comic strips; (3) creating posters, brochures, or bulletin board displays; and (4) writing stories or opinion pieces for the school newspaper; 5) performing a debate on controversial environmental topic; and 6) engaging in role plays that explore provocative environmental topics (Hauschild et al, 2012).

\section{c. Listening or reading for enjoyment}

Sometimes, it is fun to just listen or read things in English for the sake of pleasure and enjoyment. This can be done by recording and playing-back songs in English that are related to environmental education. Students can sing along with the song or just listen to it, enjoying the lyrics and music. Students can also watch movies in which its topics is about environment, such as On Deadly Ground, Pelican Brief, The Lord of the Rings Trilogy (The last episode), etc. Poems, novels, and short stories which are environmentally related can also work well with pleasure and enjoyment. The follow up activities can be making summary, discussing the moral value, characters that students can learn in relation environment, or writing of opinion about the song, the poem, the short story, or novel that students read.

\section{Model 2}

a. Self-reported

Students tell/write about their own or classmates' participation. This includes when students interview each other. For example, students work in groups, then ask friends in the group about what they do to participate in greening their surrounding environment, or asking how 'green' their daily activities are. Students can give examples of activities and reasons why they think their activities are green. Before doing this activity, teacher should prepare a list of possible questions to ask. After doing self-reported activity, students should present the report orally with the help of media, such as slide presentation, pictures, real objects, or other form of media. Students can also give written self-report, but then they still should share it with all friends in class.

b. Reported

The reported activity can be done in several ways. First, students report on the participation of others outside their class by gathering data or by remembering, for example, students are required to observe their surrounding neighborhood to spot someone who, in their understanding, take participation in protecting the earth. This someone can be anybody, such as a gardener, a trash picker, an organic farmer, a mother who turns off all electric equipment when they are not used, etc. In writing the report, students should gather more data by searching it from the magazine, books, library, or internet. Second, teachers can also organize field trips to local recycling 
centers, if they exist, to learn how important recycling is, how the process works, and what items can and cannot be recycled. And third, bringing the world into the classroom by inviting a guest speaker that has given a contribution in saving/protecting the earth can also be a brilliant idea to do. Invited guest speakers - both native and non-native English speakers - can educate students about local environmental issues and help students understand what can be done to make a difference. These guest speakers can be someone who has devoted his/her life in saving the orangutan, or the inventor of environmentally friendly plastic bag, or a factory owner who produces recycled product, a group of people who teach their neighborhood how to recycle particular items, etc. Prior these activities, students should take notes. Afterwards, they can prepare an oral or written response in which they explain both what they learned and what they can do to be more environmentally responsible.

c. Read about/listened to

Students read a text or listen to a tape about how others participate or could participate. Teachers can provide authentic texts downloaded from the internet in relation to environmental issues. Many texts are available, some are even equipped with worksheet and its answer that ease teachers in using the materials. The teacher, however, should be very keen in choosing the materials. The activities in the text should constitute either participation or the description of activities in relation to earth protection. During teaching, students should be posed with higher order thinking questions that can propose their critical thinking.

d. Recommended

A text urges students to participate, This can be done through listening sections or reading sections. Teachers may read a text in which its contents is to recommend students to participate in recycling or using used items. The text may discuss about what people can do to save the energy. Or, the text may in the form of listening section which urge people to do something to protect the earth. The following example is taken from Belgrave (in Jacobs and GoatlyBelgrave, 2000), students listen to an audiotape on which an environmentalist says 'And, when you've worn out the clothes, or you've got tired of the clothes or the toys ... actually handing them on to someone else is a very good way of recycling and reusing, which is extremely environmental friendly ...'

e. Simulated

Students role-play typical situations, or imagine that they are in a position to participate in efforts to protect the environment. This can be done with the help of situational dialogues prepared by the teacher before hand. The situation perhaps one becomes the organic farmer and other becomes the conventional farmer, and the two have exchange dialogue on the advantages of organic farming. Or one who plays as the organic farmer gives tips to conventional farmers on how to grow plants without endangering the ecosystem. Other situation perhaps a role play among mayor candidates of a region in which its ecosystem is badly damage because of the illegal logging. The contestants then give their arguments of what they will do to stop the illegal logging and to restore the ecosystem.

f. Potential action

Students tell/write/choose what they or others will/ could/would do. For example, students are asked to make lists of what they can do to solve the environmental problems they find around the neighborhood. The instruction can be given like this, "Mention 5 things that you can do to minimize the use of plastics", or "List 5 things that you can do to make people aware of the danger throwing trash into the river", or "Mention 5 things that you 
can do at home or at school to reduce the amount of daily garbage", or "What are your best ideas to green your home/school environment?", etc. The activities should be shared with everybody in the class either written or oral.

\section{g. Real}

What students are assigned to do, or what is listed as an optional assignment. Jacobs and Goatley (2000) thought that such real participation can be done in three possible types, namely a) Educational: Students try to educate others, e.g. by making posters and displaying them; b) Behavioral: Students do something that directly helps the environment, c) Exerting pressure: Students may send letters to companies and governments in an attempt to bring pressure on them to participate in helping the environment.

From these activities, students will be connected with lives beyond school. This connection can give them opportunities to be aware of the problems of real life, and environmental issues certainly offer many opportunities for such connections.

\section{CONCLUSION}

This paper have presented some ideas about what and how ELT teachers can do to educate students in a holistic way, that is

\section{REFERENCES}

Cates, K. (1990). Teaching for a better world: Global issues in language education. The Language Teacher 14: 3-5.

Education world. (2011). Twenty-Five Activities for Building Student Character, School "Community". (Online), (http://www.educationworld. com/a_admin/admin/admin 364 . shtml). Accessed 17 December 2012

Gürsoy, E. (2010). Implementing environmental education to foreign language teaching to young learners. Educa- helping the students to become better citizens and, at the same time, they become more proficient in a new language. One might argues, however, that the inclusion of environmental education in the English language classroom is not as easy as it may seem. It is worth trying though if we actually look forward to the welfare of our environment. The inclusion of environmental issues in ELT basically gives teachers and students a chance to create a better world for living.

In relation to character education, teachers need to realize that character building should not only be written as part of lesson plan. To build the expected characters within individuals, students need to have good models that they can learn from and reflect upon, or having the experience of doing certain action that can trigger their inner drive. Creating students who are environmentally aware and able to take participation to protect their environment basically help them to posses good moral values. For example, students who get used to throw trash on the waste bin and who like to grow plants and take care of animals are usually those who have discipline, caring and responsible characters. Thus, helping them to acquire environmentally friendly behaviors are equally importance as helping them to acquire good characters within individuals.

tional Research, 1, (8), 232-238.

Gürsoy, Esim and Gülderen T. Sağlam. (2011). ELT Teacher Trainees' Attitudes Towards Environmental Education And Their Tendency To Use It In The Language Classroom. Journal of International Education Research Fourth Quarter 2011 Volume 7, Number 4: $47-52$.

George, and Andrew Goatly. (2000). The Treatment of Ecological Issues in ELT Coursebooks. ELT Journal 54: 
256-264.

Jacobs, G. M. and Goatly, A., (2000). The treatment of ecological issues in ELT coursebooks. ELT Journal, 54(3), 256264.

Hauschild, Staci, Elena Poltavtchenko, Fredricka L. Stoller. (2012). Going Green: Merging Environmental Education and Language Instruction. English Teaching Forum, 1, 1 - 12.

Kemdiknas. (2010). Panduan Pendidikan Karakter di Sekolah Menengah Pertama. Jakarta: Dirjen Dikdasmen

Nkwetisama., Carlous Muluh . (2011). EFL/ ESL and Environmental Education: Towards an Eco-Applied Linguistic Awareness in Cameroon. World Journal of Education. Vol . 1, No. 1; April 2011: 110-118

Purnomo, Haryono Adi. (2012). Strategi Habituasi dalam Nilai-Nilai Pendidikan Karakter Bangsa di Sekolah. (online), ( http://haryonoadipurnomo.wordpress.com/2012/01/11/ strategi-habituasi-dalam-implementasi-nilai-nilai-pendidikan-karakterbangsa-di-sekolah/), accessed on 14 December 2012.

Reddy. (2007). School Quality: Perspectives from the Developed and Developing Countries. Azim Premji Foundation.

Malino, Jupri. (2012). Tujuan Pendidikan Karakter Dan Karakter Yang Diharapkan. (online), (http://juprimalino.blogspot.com/2012/04/tujuanpendidikan-karakter-dan-karakter. html), accessed on 17 December 2012.

Suyanto, Prof, Phd. (2009). Urgensi Pendidikan Karakter. Direktorat Jenderal Manajemen Pendidikan Dasar dan Menengah . (online), (http://www. mandikdasmen.depdiknas.go.id/ web/pages/ urgensi.html), accessed on 17 December 2012.

UNESCO-UNEP. (1976). The Belgrade Charter: A Global Framework for Environmental Education. Connect 1 (1): 1-9. 
